\title{
Digital Banking in Indonesia: The Development of Cashless Culture and Regulations
}

\author{
Henry Aspan', Anggi Pratama Nasution ${ }^{2}$, Ikhah Malikhah ${ }^{3}$ \\ ${ }^{1,2,3}$ Universitas Pembangunan Panca Budi, Medan, North Sumatera, Indonesia \\ Corresponding Author: Henry Aspan
}

DOI: https://doi.org/10.52403/ijrr.20220162

\begin{abstract}
As a business, banking adheres to the concept of a trust business. When it comes to risk management, this is where the bank truly has to be at its best. As a result, banks like Bank Indonesia and OJK may rest easy knowing that they are in accordance with the law. However, banks are particularly concerned about reputation risk, which has an impact on customer trust and is crucial for banks to manage. As part of digital banking's infrastructure and banking technology, security and transaction simplicity must also be addressed.
\end{abstract}

Keywords: Electronic Money, Regulation, Transaction, Legal System.

\section{INTRODUCTION}

Several banking businesses have recently started to shift their company growth strategies toward digital. This was also prompted by the Bank of Indonesia's strategy, which advocated the establishment of a cashless society. A cashless society is one in which individuals no longer use currency to make payments. The public may pay using electronic devices such as debit cards, credit cards, or other electronic money.

Bank Indonesia (BI) launched the National Non-Cash Movement in 2014 to promote the use of electronic money. The government has introduced non-cash transactions, particularly in major cities, such as payments for Trans Jakarta transit services, KRL, and toll gate payments.
Apart from becoming more practical and efficient, individuals will no longer need to carry currency, reducing the potential for theft and the hassle associated with carrying significant sums of cash. Bank Indonesia (BI) predicted that the Indonesian people would eventually abandon cash in favor of cards for all transactions.

The following are the economic consequences of Indonesia's "cashless society."

\section{Facilitate transactional activities.}

Transacting cashlessly may simplify transactions and provide for easy tracking. From the number of transactions to the location and time, all the information is readily accessible. As opposed to digital transactions, cash has a number of disadvantages, including storage convenience.

\section{Tax collection will be enhanced.}

The resultant tax may be used to fund infrastructure development, raising government income and also stimulating Indonesia's economic growth.

\section{Money Circulation Becomes More Rapid \\ A "Cashless Society" might} potentially speed up money circulation in the Indonesian economy. People may now conduct a variety of transactions more easily using e-money. Additionally, the bank will collect a commission on all electronic money, debit card, and credit card transactions. 


\section{Boost Security.}

Additionally, a cashless society has the potential to reduce crime and theft rates since cash is no longer a popular target. This strategy eliminates the possibility of receiving fake money. Making cashless payments helps society as well. The public will be provided a variety of enticing promotions and be exposed to the concept of cashback. Thus, one might argue that the "cashless society" helps both the populace and the Indonesian economy.

According to Network Prima Indonesia's article "Indonesia towards cashless society," being a cashless society has unique challenges.

To begin with, cashless payment systems are infrastructure and technologydependent. A communication network system, an internet connection, electricity, and other devices such as EDC machines, ATMs, card readers, and smartphones are required to conduct transactions using APMK or money. As a result, if there is difficulty accessing one of these infrastructures or technologies, the transaction process may be disrupted.

Second, consumer protection measures are required to preserve and grow customer trust in cashless payments. Personal data theft and cyber threats must be anticipated via ongoing system updates. Consumers may also enforce self-security standards by not sharing PIN or OTP numbers with others and by changing PIN numbers on a regular basis.

Third, despite significant technology advancements, a sizable proportion of Indonesians continues to pay with cash. This is prompted by the sociocultural circumstances in the community, which are already used to utilizing cash for transactions, as well as the barriers to community access to financial products and services. According to the Financial Services Authority's (OJK) third national financial literacy survey, the financial literacy index reached 38.03 percent in 2019. This illustrates the community's financial literacy. While the financial inclusion index now stands at 76.19 percent, this statistic implies that individuals have access to financial products and services.

By overcoming these three challenges, we can achieve a cashless society. Banks must exercise caution while establishing cashless or digital banking solutions in order to minimize these issues. Finally, but certainly not least, it is essential to pay special attention to the target market. Because the appropriate target market has an effect and influence on how people behave when it comes to cashless financial transactions. Banks must determine if this target is a sizable group and the effect it will have on their banking operations.

Apart from that, does this digital banking service meet client demands and is it suitable for current settings and circumstances? And what are the impediments and risks associated with this business, as well as how can banks reduce the risk associated with this "threat"?

Banking is a prudent business principle that conforms to what is referred to as a trust business. This is where the bank must really be capable of risk management at its best. This is advantageous since it satisfies a banking compliance requirement imposed by regulators such as Bank Indonesia and OJK. However, this is critical for banks in terms of managing reputation risk since banks are very sensitive to what is referred to as "reputation risk," which has an effect on consumer trust. Infrastructure and banking technology must also be addressed in terms of security and transaction simplicity in digital banking.

\section{DISCUSSION}

Quoting from the Marketing 4.0 book "Moving from traditional to digital" by Philip Kotler, Hermawan Kertajaya, and Iwan Setiawan. In other words, the influential digital subculture consists of three groups that are very influential. These three groups are:

- Youth to exchange ideas

- Women's participation in the market

- Netizens will share emotional posts. 
Not all customers are created equal when it comes to brand defense in the digital realm. As a result, particular segments rely on their personal preferences and what they hear in commercials, and as a result, the defense is irrelevant to them. Additionally, they do not share their experiences. Other groups are more likely to seek out and provide brand recommendations. They are the individuals who are most likely to become loyal supporters of a product or brand.

To boost their chances of obtaining a defense, marketers must invest in youth, women, and netizens (YWN-Youth, Women, and Netizens). Numerous subjects have been examined and developed independently of these three primary segments. Each is a highly lucrative segment in terms of size. As a result, their marketing strategy is especially adapted to their requirements.

For example, for young people to establish their own trends, particularly in areas of popular culture such as music, cinema, sports, cuisine, fashion, and technology, seniors often lack the time and dexterity to properly examine rapidly changing popular culture; instead, they just follow and depend on young people's suggestions. Because young customers are often the first to test new products, they are frequently the primary focus of marketers. When a new product is accepted by young people, it is often effective in reaching the general market.

In many countries, women serve as the family's financial officers. Women's voices often outweigh men's views when it comes to purchasing a brand across a variety of product and service categories. This is because the majority of women have the patience and enthusiasm to go through a lengthy process of studying the best solutions, which the majority of men find pointless or even unpleasant. As a result, women play a critical role in serving as gatekeepers for any product or service presented to families by marketers.
Additionally, netizens have considerable influence. They are quite aware of how to engage with other people online while providing information as digital actors. While not all of their information is useful and not all of their behaviors are beneficial, they are an excellent example of a savvy customer. Representing what they perceive to be a borderless democracy, they openly share their ideas and sentiments about companies, often anonymously. They provide ratings, post (published) comments, and even create content that citizens notice. Their support of a brand has a significant impact on how a product is marketed.

Banks have started developing digital banking solutions to satisfy the demands of these three main market segments. For instance, how can these three market groups embrace a cashless society implemented by a bank via its electronic financial services, such as mobile banking? Is Mobile Banking Simple to Use for Millennials and Young Adults? And if the services supplied by mobile banking are capable of meeting the expectations of millennials who like virtual shopping through online marketplaces. Additionally, one must assess if the mobile banking function will provide significant advantages in terms of supporting the lifestyles of millennials who want to hang out in cafes, coffee shops, and similar establishments. Banks must be on the lookout for this chance. Similarly, in assessing if this digital banking solution can assist housewives or professional women who are also housewives,

For instance, can the features of a bank's mobile banking accommodate these women in order to enable them to make regular monthly bill payments without visiting the bank or the company to which they subscribe, such as school fees, child tutoring fees, or payment of water, electricity, and telephone bills, among others? Similarly, with netizens, the question is whether this digital banking function can meet the demands of 
individuals who are always online. Can the digital banking product's features assist users in determining the need for additional/purchased internet quota, payment for internet subscriptions, and the ease with which they can access their EWallet to conduct online transactions?

According to the bank, the development of digital banking products can focus on the needs of these three target market groups.

\section{Changes in Payment Behavior}

According to the findings of the Ipsos Indonesia research "The Next Cashless Society," performed in early 2020, there has been a shift in the payment behavior of individuals who are beginning to transition toward a cashless society. When it comes to cashless payment instruments, there are three distinct features of the customer group. Consumers think that cashless payments are secure, convenient, and efficient, as well as providing them with the ability to manage their expenditure.

Consumers prefer non-cash payments because they provide a positive experience and allow for the development of interactions with other individuals. Consumers are seeking more competent and user-friendly cashless products, and consumers who are new to cashless payments perceive a series of benefits.

In the past five years, electronic money adoption has accelerated in Indonesia. When GNNT was released in 2014, there were 35.7 million electronic money instruments in circulation. In 2019, this figure had increased to 292.2 million instruments, a more than ninefold increase. In 2014, electronic money transactions totaled IDR 3.3 trillion. In 2019, the transaction amount increased more than fivefold to IDR 16.9 trillion.

In terms of card-based payment instruments, 112.9 million ATM/debit cards were in circulation in 2014. In 2019, the number of ATM/debit cards increased by more than $54 \%$ over the previous year to 174.4 million.In 2014, there were 7.1 million ATM cards in circulation. The total number of ATM cards in circulation reached 8.9 million in 2019, an increase of more than $25 \%$ over the previous year. In 2014, there were 16 million credit cards in circulation. In 2019, that number increased by approximately 8.75 percent to 17.4 million cards.

\section{The Advantages of a Cashless Society}

Being a cashless society improves the security, convenience, and efficiency of payment. Payments are secure because they are made using a PIN or a unique code (OTP) that prevents fake money. It's convenient since users don't have to carry cash or bear the disappointment of being out of change; it's efficient because transactions using cards (deep/swipe on the EDC machine or touch on the card reader machine) or smartphones are simpler and quicker (scanned QR code). The following advantage is that financial planning may be more accurate. Non-cash payments enable the accurate and detailed recording of all transactions. Additionally, consumers can easily track all revenue and spending, including transaction amount, location, and time, as well as the merchant name. Selfdiscipline in budgeting is critical to success. Finally, As a result, practically all banks, particularly Bank Book IV, implement innovations and investments to enable digital business development. Along with Bank Indonesia's orders, this was prompted by the fact that various banks started to focus on Millennials, who began to account for the majority of their customer base or potential clients.

\section{Technology as a Critical Factor in the Transition to Digital Banking}

According

to

http://www.celent.com/reports/definingdigital-financial-institution-what-digitalmeans-banking, the Financial Services Authority, and R \& D technologybank.com, within the next decade, technology will evolve to a point where it will control several areas. At the moment, technology is 
utilized not only in the workplace but also in other spheres of life, such as at home and in numerous locations. As a result of this fast advancement, human resources will be less necessary in the coming decade as a result. All of these will be supplanted by technology or robots capable of doing human duties automatically. This includes the banking sector, which is only beginning to use technology to facilitate consumer interactions.

Additionally, people are becoming more literate as a result of technological advancements. Banks must adapt to changing times. For instance, in the past, anybody wishing to transact had to visit a branch office or an ATM machine. However, as a result of technological advancements, there is a movement toward mobile and online banking. As a result, there is no need to visit the bank and make contact with the front office, teller, or customer service representatives. They are all possible on their own.

The existence of technology will crush bank branch operations controlled by tellers. The position of the teller has declined significantly over the previous 15 years, and the next decade will see the majority of employment eliminated in more modern kinds of ATMs. According to the analysis, teller positions would decline by $8 \%$ over the next decade, from 2014 to 2024. The digital revolution is affecting businesses of all sizes, including banking.

Technological advancements in the transition of financial services from traditional to digital do not exclude the potential of bank branch office rationalization. Numerous branch offices have been shuttered as a result of the high volume of transactions conducted via them. This is also reinforced by bank clients in Indonesia, who have started to develop an understanding of technology. Customers seldom visit branch locations to conduct transactions; instead, they utilize the bank's own internet and mobile banking facilities. That is why bank workers must also prepare for significant technological advancements in this digital age.

There will be a massive shift away from traditional banking toward digital banking, which requires less labor. As a result, everyone must possess particular capabilities in order to survive. Along with the age of free competition in the Asean economic community's financial sector in 2020, banks must have determined which sections of their operations will be reduced to compete with other countries.

According to Vibiz Research Center Senior Analyst in an essay titled "The Role of Technology in the Digital Era and the Impact on Banking."To prepare for increasingly advanced, competitive, and integrated developments in information, communication, technology, and innovation, Bank Indonesia also issued a set of regulations governing the national payment system with the goal of fostering integrated and sustainable development resilience, as well as increasing competitiveness through national payment gateways.

The National Payment Gateway (NPG) serves the community's requirements for non-cash transactions by facilitating and expanding the community's use of retail payment instruments.

In conclusion, as digital technology advances and an increasing number of individuals undertake non-cash transactions through online banking or mobile banking, accordingly:

- Banks need to prepare digital banking products for

- Banks need to conduct an assessment of their operational systems and infrastructure used

- Banks need to assess how many branches they have ideally.

- Banks need to equip human resources who have the skills to carry out banking operations.

- The digital era has arrived and will affect lifestyle and financial devices, so banks that are not prepared will be left behind. 


\section{The COVID-19 Pandemic Era and Digital Banking.}

Fortunately, banks have capitalized on their businesses via digital banking products. Since the COVID-19 pandemic spread to Indonesia, several areas have physical distancing rules, resulting in restricted community mobilization from one location to another. Thus, digital banking is the predominant way of retaining access to banking services and e-commerce, or online transactions.

Bank Indonesia (BI) noted in a fund market article dated June 19, 2020 that the number of digital banking transactions surged considerably by 37.35 percent in April 2020 (yoy).

This result demonstrates the growing importance of digital commercial and financial activities during the COVID-19 epidemic. Economic transactions through digital are accelerating, which benefits individuals whose activities have "accelerated virtually," BI Governor Perry Warjiyo remarked during a teleconference in Jakarta on Thursday (18/6/2020). In general, the central bank asserts that the payment system, both cash and non-cash, operates smoothly and is well maintained. In May 2020, the circulating currency position reached Rp. 798.6 trillion, a decrease of 6.06 percent (yoy). This is consistent with the effect of decreased money demand, both as a result of diminishing economic activity during the COVID-19 epidemic and as a result of the delayed Eid al-Fitr vacations."

In accordance with declining economic activity, non-cash transactions through ATMs, debit cards, credit cards, and electronic money (EU) decreased by minus 4.72 percent in April 2020, from minus 4.72 percent in March 2020 to minus 18.96 percent in April 2020 (yoy). In April 2020, electronic money transactions increased by 64.48 percent year on year, while digital banking transaction volume increased by 37.35 percent. This trend demonstrates a growing demand for digital economic and financial activities, including an increase in public acceptance of digital payments over the PSBB era.

It may be inferred that Indonesia's economy continues to flourish due to the availability of digital banking products and non-cash transactions that can meet the community's demands during the COVID19 epidemic. This is, of course, a benefit for the bank since numerous areas within the bank faced a slowdown, including credit growth and increasing bad loans, resulting in greater bank reserves for bad loans, which is associated with bank profit erosion. However, the rise in non-cash transactions through digital banking products benefits banks in terms of transaction fees. Additionally, the use of third-party funds in banking rose, as did the use of digital banking products.

\section{Legal Requirements for Digital Banking}

The Financial Services Authority (OJK) has issued regulations addressing digital bank services in OJK Regulation Number 12/POJK.03/2018, relating to commercial banks' implementation of digital banking services. Additionally, OJK has established recommendations on digital bank services in the form of Guidelines for Commercial Banks' Implementation of Digital Branches.

Digital banking offers similar services to traditional banking, but with one distinction: all financial activities are conducted independently through banking applications on smartphones. Without needing to visit the bank directly, digital banking enables users to access financial services independently (self-service).

According to the Financial Services Authority (OJK), digital banking services enable prospective customers and/or bank customers to obtain information, communicate, register, open accounts, conduct banking transactions, and close accounts, as well as obtain information and conduct transactions not related to banking products, such as other financial advisory, investment, electronic-based trading system 
transactions (e-commerce), and other banking-related needs.

Along with regulations governing digital bank services, OJK also publishes Guidelines for Commercial Banks' Implementation of Digital Branches.

According to the website OJK.go.id, there are various rules pertaining to digital branches and digital banking. The bank is expected to produce a strategy plan for digital banking development, which must be backed up by the bank's information technology infrastructure. Then it specifies how information technology is managed in connection with the development of bank digital goods. Among these are those concern;

- Opening of digital branches as a means for customers to be able to open their digital banking products.

- Is this form of digital branch comparable to a cash office or something else?

- The Digital Branch arrangement is integrated with the Cash Office.

- Digital Branch Settings in Overseas Branches

The authors devote particular attention to the risk management settings of the information technology system for digital banking, based on many recommendations provided by OJK. Because we are discussing ways to avoid the risks associated with digital banking transactions in this section, wherever risks occur, there will be a case for or against banking. As a result, it is vital to consider risk mitigation strategies for this information technology.

In the OJK's Guidelines on the Use of Digital Branches for Information Technology Risk Management:

Banks must address the following issues when adopting information technology risk management for the operation and establishment of digital branches:

1. Security Logic:

- Applying the principle of two factor authentication at the time of registration
/ registration of prospective customers and at the time of transactions.

- Utilizing the two-factor authentication concept during the registration and registration of potential consumers and during transactions

- Using e-KTP as a database and for customer verification.

- Utilizing an e-KTP reader that has been certified in compliance with relevant laws by the appropriate authorities

- Save image. e-KTP image of a potential consumer

- Keeping track of potential customers in order to execute the APU-PPT program

- Validate some prospective customer data against Disdukcapil population statistics.

- Determine the maximum tolerance for data verification input errors.

- Maintain the confidentiality of customers' or potential customers' personal information during the registration process, transactions, and other services.guaranteeing compliance with relevant rules for all devices and apps used in the digital branch.

- Storing prospective customer information for the implementation of the APU-PPT program

- Ensuring that all devices and applications used in the digital branch have complied with the applicable regulations.

2. Physical security:

- Perform security on all facilities and infrastructure, such as e-KTP reader machines, terminals, and network cables.

- Using electronic devices that are tempered-proof

- Operate Closed Circuit Television (CCTV) cameras which can cover the entire digital branch area and supporting infrastructure and store CCTV camera recordings for a certain period according to bank policy. 
3. Operational control:

- Provide guidelines, explanations, and illustrations of the types and ways of using services at the Digital Branch as part of the education and customer protection aspects.

- Verify and ensure the validity and suitability of the cellular phone number registered by the customer, among others, by sending a one-time password (OTP) code to the cellular phone number registered by the customer.

- Provide proof of transactions in electronic and/or printed form to customers.

- Provide notification services to customers for certain types of transactions in accordance with the bank's risk appetite or customer needs.

- Have a method for monitoring Digital Branch activities, including providing an audit trail of the system used to support the implementation of the Digital Branch.

- It has a mechanism to ensure log security on e-ID card reader machines.

- Maintain security and confidentiality of biometric data in the event that the bank records biometric data of prospective customers.

- Provide telephone facilities at the Digital Branch to communicate with the Call Center.

- They have functions and procedures to handle customer complaints and resolve disputes related to digital transactions.

- They have an adequate Disaster Recovery Plan (DRP) to ensure the availability of services at the Digital Branch.

- Audit the digital branch infrastructure at least once a year.

- Ensure that third parties in collaboration with the bank implement adequate security controls at least in accordance with the bank's risk appetite and standards, in the event that the services provided by the bank are the result of cooperation and/or third party products.
When a client initiates a transaction for the opening or registration of a bank account, the business process remains unchanged, indicating that they are still paying attention to two of the three authentication requirements.

Along with the OJK's regulations on digital banking, it is governed by the Law on Information and Electronic Transactions. The Law on Information and Electronic Transactions (abbreviated as UU ITE), or Law No. 11 of 2008, is a piece of legislation that controls information and electronic transactions, as well as information technology in general. This law has jurisdiction over anyone who does legal acts as defined in this law, both inside the territory of Indonesia and beyond its jurisdiction, that have legal repercussions in Indonesia and/or beyond its jurisdiction and jeopardize Indonesia's interests.

In one section, the discussion of the ITE Law also regulates e-commerce and the theft of bank customer data (cyber crime). Bank Indonesia Regulation No. 20/6/PBI/201 Concerning Electronic Money (hereinafter referred to as "PBI 20/2018").In the regulation, what is meant by "electronic money" is a payment instrument that meets the following elements:

- Issued on the basis of money placed in advance with the issuer;

- Money is held electronically in a media server or chip, and

- The value of electronic money managed by the issuer is not a deposit as defined by the Act regulating banks.

Even though it is not in physical form, electronic money must adhere to the rules of the laws and regulations governing the mandatory use of Rupiah for payment transactions performed inside the Unitary State of the Republic of Indonesia's territory. Additionally, electronic money issued in Indonesia must be denominated in Rupiah. Similarly, transactions involving electronic money that take place within the territory of the Unitary State of the Republic of Indonesia must be conducted in Rupiah. Thus, from our perspective, what occurred 
was not the rejection of Rupiah payments but the encouragement of Rupiah conversion to electronic form. The value of electronic money is still regarded as the Rupiah.

This conversion effort is motivated by a variety of benefits associated with electronic money. As stated by Rachmadi Usman in his article "Characteristics of Electronic Money in Payment Systems" in the Yuridika Journal-Faculty of Law, Airlangga University, Volume 32 No. 1 (p. 136), the emergence of electronic money is a response to the need for micropayment instruments capable of processing payments quickly and at a low cost, because the value of money stored by these instruments is generally fixed. Thus, electronic money is meant to facilitate and expedite payment processes.

\section{CONCLUSION}

According to the argument above, technological growth cannot be halted since it is directly proportionate to the human demand for convenience in all activities. One of them is financial activities, which have direct interaction with banking services on a daily basis.

This is also consistent with the changing banking market segmentation, which has shifted away from Generation X and the Baby Boomer generation and toward Generations Y and Z (Millennials), who are already highly technologically literate to the point where traditional banking is no longer appealing to them. This is why banks must be adaptable in order to survive and win market competition. Additionally, the regulator has controlled this via the Financial Services Authorization (OJK), which set rules about digital bank services in OJK Regulation Number 12/POJK.03/2018, regarding the Implementation of Digital Banking Services by Commercial Banks. Furthermore, OJK has established recommendations on digital bank services in the form of Guidelines for Commercial Banks' Implementation of Digital Branches.
The bank may supply and grow digital banking services while minimizing risk and ensuring the services are secure in terms of procedures and technology employed. As a consequence, each banking transaction with a consumer is guaranteed, and this is becoming more critical and crucial as the COVID-19 epidemic spreads to practically every country on the planet, where physical separation is necessary to conduct these activities from home, and work, school, and worship are conducted from home. Because leaving the home is only suggested for really necessary reasons. Thus, clients need digital transactions since they can be accessible from their homes. Transacting through digital banking is the most prudent course of action in light of the current epidemic.

\section{Suggestion}

The inevitable advancement of technology has resulted in an evolution that has made it simpler for people to fulfill their wishes in all of their endeavors. And this should be a warning sign for all businesses, particularly banks, to strengthen their skills, both human and technological, in order to continue serving the community in a variety of scenarios and conditions.

\section{Acknowledgement: None}

\section{Conflict of Interest: None}

\section{Source of Funding: None}

\section{REFERENCES}

1. Kotler, Philip dan Hermawan Kartajaya. (2019). Buku Marketing 4.0 "Bergerak Dari Tradisional Ke Digital "karangan Philip Kotler- Hermawan Kertajaya dan Iwan Setiawan.

2. Novelina Mutiara Sariati Hutapea. (2021). Jurisdictional Review of the Perpetrators of the Dissemination of Customer Data Committed by Online Loans. Internation Journal of Advance Research and Innovative Ideas in Education, 7(2), 16231627. 
3. Rachmadi Usman. (2017). Karakteristik Uang Elektronik dalam Sistem Pembayaran, Jurnal Yuridika - Fakultas Hukum Universitas Airlangga, Vol. 32 No. 1.

4. Undang-undang No. 11 Tahun 2008 tentang Informasi dan Transaksi Elektronik.

5. Peraturan Otoritas Jasa Keuangan No. 12/POJK.03/2018 tentang Penyelenggaraan Layanan Perbankan Digital Oleh Bank Umum.

6. Website www.celent.com/reports/definingdigital-financial-institution-what-digitalmeans-banking, artikel berjudul "Defining a Digital Financial Institution: What "Digital" Means".

7. Website www.ipsos.com/en-id/ipsos-mediaconference, hasil studi terkait "The Next Cashless Society" yang dilakukan Ipsos Indonesia di awal tahun 2020.
8. Website www.jaringanprima.co.id/id/indonesiamenuju-cashless-society, artikel yang berjudul, "Indonesia menuju Cashless Society".

9. Website Otoritas Jasa Keuangan, www.OJK.go.id.

10. Website www.vibiznews.com, artikel tulisan Belinda, Analyst Vibiz Research Center yang berjudul "Peran Teknologi di Era Digital dan Pengaruhnya Terhadap Perbankan.

How to cite this article: Henry Aspan, Anggi Pratama Nasution, Ikhah Malikhah. Digital banking in Indonesia: the development of cashless culture and regulations. International Journal of Research and Review. 2022; 9(1): 534-543. DOI: https://doi.org/10.52403/ijrr. 20220162 